\title{
Sulfide, Sulfite, and Sulfate Production from Organic Sulfur in Archean Oceans and Modern Lakes
}

\author{
SERGEI KATSEV ${ }^{1 *}$, MOJTABA FAKHRAEE ${ }^{1}$, EMILY \\ HYDE $^{1}$, MADELYN PETERSEN ${ }^{1}$, CODY SHEIK ${ }^{1}$, KATHRYN \\ SCHREINER $^{1}$
}

${ }^{1}$ Large Lakes Observatory, University of Minnesota Duluth, 2205 E. $5^{\text {th }}$ St., Duluth, MN, USA 55812.

*Correspondence: skatsev@d.umn.edu

The chemistry of the Early Earth is widely inferred from the elemental and isotopic compositions of sulfidic sedimentary rocks, which are presumed to have formed globally through the reduction of seawater sulfate or locally from hydrothermally supplied sulfide. Here we argue [1] that, in the anoxic Archean oceans, pyrite could form in the absence of ambient sulfate from organic sulfur contained within living cells. Sulfides could be produced through mineralization of reduced sulfur compounds or reduction of organic-sourced sulfite. Reactive transport modeling suggests that, for sulfate concentrations up to tens of micromolar, organic sulfur would have supported 20 to $100 \%$ of sedimentary pyrite precipitation and up to $75 \%$ of microbial sulfur reduction. This offers an alternative explanation for the low range of $\delta^{34} \mathrm{~S}$ in Archean sulfides. Investigations of the sulfur cycling in modern low-sulfate environments reveal the production of solid sulfides from organic sulfur, and metagenomic data point to the presence of complete metabolic pathways for the utilization of several common organosulfur compounds. The results point to a previously unrecognized key role of living cells in throttling the Archean sulfur cycle, underscore the importance of sulfite, and raise a possibility that sulfate scarcity delayed the evolution of dissimilatory sulfate reduction until the initial ocean oxygenation around $2.7 \mathrm{Ga}$.

[1] Fakhraee \& Katsev (2019) Nature Communications 10, 18. 